\section{Protection of children and adolescents victims of violence: the views of the professionals of a specialized service}

Priscila Arruda da Silva'

Valéria Lerch Lunardi² Rodrigo Dalke Meucci ${ }^{3}$

Simone Algeri ${ }^{4}$

Protection of children and adolescents victims of violence: the views of the professionals of a specialized service

Objective. To know the obstacles faced by the professionals to work in network and challenges of the work of the professionals in the Reference Center Specialized in Social Assistance (CREAS) of a municipality in the extreme south of Brazil. Methods. It is a qualitative study, developed with twelve professionals of a CREAS. Data collection was performed through a semi-structured interview, from April to May 2016. The interviews were submitted to content analysis. Results. The fragmentation among the various services that make up the victim assistance network is an obstacle for professionals as they are unable to continue the recovery and health promotion actions of these families. The professionals point out the bureaucratic procedures, the accumulation of functions and the lack of human and financial resources as a routine problem and that seriously hinders the progress of the service. Conclusion. For the professionals, the protection network



1 Nurse, Ph.D. Scholarship PNPD, Federal University of Rio Grande -FURG-, Brazil.

email: patitaarruda@yahoo.com.br

2 Nurse, Ph.D. Retired Professor, FURG, Brazil. email: vlunardi@terra.com.br

3 Physiotherapist, Ph.D. Professor FURG, Brazil. email: rodrigodalke@gmail.com

4 Nurse, Ph.D. Professor Federal University of Rio Grande do Sul, Brazil.

email: salgeri@terra.com.br

Conflict of interest: none.

Receipt: March 27th, 2018.

Approved: September 19th, 2018.

How to cite this article: Silva PA, Lunardi VL, Meucci RD, Algeri S. Protection of children and adolescents victims of violence: the views of the professionals of a specialized service. Invest. Educ. Enferm. 2018; 36(3):e02.

DOI: $10.17533 /$ udea.iee.v36n3e02 
presents weaknesses that compromise the guarantee of the rights of children and adolescents.

Descriptors: adolescent; child; exposure to violence; child advocacy qualitative research.

\section{Protección a niños y adolescentes víctimas de violencia: miradas de los profesionales de un servicio especializado}

Objetivo. Conocer la problemática de la violencia intrafamiliar contra niños y adolescentes a partir de la percepción de los profesionales de un Centro de Referencia Especializado en Asistencia Social (CREAS) de un municipio del extremo sur de Brasil. Métodos. Se trata de un estudio cualitativo desarrollado con doce profesionales de un CREAS. La recolección de datos se realizó mediante una entrevista semiestructurada, en el período de mayo a junio de 2016. Los testimonios se sometieron al análisis de contenido. Resultados. Entre los diversos servicios que componen la red de atención a las víctimas, la fragmentación es el principal obstáculo para los profesionales en medida que no logran dar continuidad a las acciones de recuperación y promoción de la salud de familias afectadas. Los trámites burocráticos, la acumulación de funciones y la falta de recursos humanos y financieros son destacados por los profesionales como un problema rutinario que dificulta seriamente la prestación del servicio. Conclusión. Para los profesionales, la red de protección presenta fragilidades que comprometen la garantía de los derechos de niños y adolescentes. 
Descriptores: adolescente; niño; exposición a la violencia; defensa del niño; investigación cualitativa.

\section{Proteção a crianças e adolescentes vítimas de violência: olhares dos professionais de um serviço especializado}

Objetivo. Conhecer os obstáculos enfrentados pelos profissionais para atuação em rede e desafios da atuação dos profissionais no Centro de Referência Especializado em Assistência Social (CREAS) de um município do extremo sul do Brasil. Métodos. Trata-se de um estudo qualitativo, desenvolvido com doze profissionais de um CREAS. A coleta de dados foi realizada por meio de entrevista semiestruturada, no período de abril a maio de 2016. Os depoimentos foram submetidos à análise de conteúdo. Resultados. A fragmentação, entre os diversos serviços que compõem a rede de atendimento às vítimas, se constitui em obstáculo para os profissionais à medida que eles não conseguem dar continuidade às ações de recuperação e promoção da saúde dessas famílias. Os trâmites burocráticos, o acúmulo de funções e a falta de recursos humanos e financeiros são apontados pelos profissionais como um problema rotineiro e que seriamente dificulta o andamento do serviço. Conclusão. Para os profissionais, a rede de proteção apresenta fragilidades que comprometem a garantia de direitos de crianças e adolescentes.

Descritores: adolescente; criança; exposição à violencia; defesa da criança e do adolescente; pesquisa qualitativa. 


\section{Introduction}

ntrafamily violence has become an increasingly common social and global problem in our society. Because it is a phenomenon with deep roots, implying immediate and future damage to the physical and mental health of its victims, ${ }^{(1-3)}$ as well as the possibility of its reproduction to future generations ${ }^{(3)}$ its approach has been characterized as a public health issue. Since the implementation of the Brazilian Federal Law n. 8069 of July 13, 1990 (Statute of the Child and Adolescent-ECA), ${ }^{(4)}$ which provides for the integral protection of children and adolescents, it was established that children and adolescents are a priority, and the state, society, community, family and public power should to secure their rights, as well as to put them to safety from all forms of violence.

Thus, it demands the articulation of a network that meets the needs of approaching the problem in its complexity, through interdisciplinary and intersectoral actions. ${ }^{(5)}$ The network of protection for victims and their families, represented as "the set of significant people systems that make up the relationship links received and perceived by the individual "(5: 247) is made up of various sections, such as the Council of Law, the Guardianship Council (CT), the public prosecutor's office and the juvenile court, as well as the other institutions that provide care, such as schools, health units, shelters, among other social support networks. Among the various services that deal with situations of violence, the Specialized Reference Center on Social Assistance (CREAS), chosen as the locus of this research, constitutes an important reference point in the care of children and adolescents who are victims of violence. It is a state public unit, created by the federal government in partnership with the municipalities to meet the Federal Constitution, the Statute of the Child and Adolescent (ECA) and the Organic Law of Social Assistance - Ordinance No. 878 of 12/3/2001. ${ }^{(6)}$

This service has as its role to be in reference, in the territories, of offer of social work specialized in the Unique System of Social Assistance (SUAS) to families and individuals in situations of personal or social risk, for violation of rights. Its role in SUAS also defines its role in the service network. ${ }^{(7)}$ In order to carry out its activities, the services offered in CREAS should be developed in an articulated way between institutions and agents that operate in a given territory sharing objectives and purposes in a continuous process of information flow and permanent dialogue. ${ }^{(7)}$

Considering the importance of the work of CREAS in the attempt to minimize the damages caused by the violence suffered and to break the cycle of violence, this study seeks the answer to the following question: What obstacles and challenges that you face in your daily work? The answer to this question can support actions that advocate the organization of the network, effectiveness and networking interactions, as well as providing solutions and 
decision making, for example, the creation of public policies directed to the problems identified. In this perspective, the objective of this study is to know the obstacles faced by professionals to work together others instances and challenges the work of professionals in CREAS of a municipality in the extreme south of Brazil.

\section{Methods}

The municipality where the present study was carried out is characterized as particularly vulnerable in the situation of violence and sexual exploitation against children and adolescents. It is a port city with approximately 207,000 inhabitants, located in the southern half of Rio Grande do Sul, with the second largest port in Brazil. ${ }^{(8)}$ Rio Grande is currently one of the most vulnerable point of sexual exploitation in the Federal Highways highlighted by Childhood Brazil and the International Labour Organization. ${ }^{(9)}$ CREAS, installed in the municipality in 2002, was one of the pioneers in the implementation of this service. They attend daily denunciations of the most varied forms of violence against children and adolescents between zero and eighteen, elderly and women. It is a service that develops, among other actions, the social protection of young people in compliance with socio-educative measure of assisted freedom and community service provision.

Five social workers, five psychologists, a secretary and a social educator participated in the study. All twelve participants linked to the service accepted to participate in the study, by signing the informed consent term. The recommendations of Resolution $466 / 2012$ of the National Health Council were followed, and the Ethics Committee of the Federal University of Rio Grande, under the CAAE, approved the project: 49775415.8.0000.5324. After the authorization of the coordinator of the service, the professionals working at CREAS were invited to participate in the research. Then, they were clarified as to the confidentiality of the interviewees' identity, the confidentiality of the data and the possibility of withdrawing at any time from the research. It was also clarified the way they would be identified in the work: through the letter " $E$ " and the sequence number of the interviews (E1, E2 ... E12), thus preserving their anonymity.

The data collection took place between April and May 2016, which were previously scheduled at the professionals' workplace. The statements were recorded and later transcribed. In the data analysis, the Bardin-inspired content analysis technique was used. ${ }^{(10)}$ The data were initially organized, then analyzed and categorized in order to respond to the study objective.

\section{Results}

In the process of data analysis emerged two categories, developed below, namely: Obstacles faced by professionals for networking and Challenges of the work of professionals in CREAS.

\section{Obstacles faced by professionals for networking}

Difficulty of articulation. CREAS workers reported difficulties in the different services that make up the protection network, such as lack of articulation and communication between services, as evidenced by the following statements. There is a great difficulty of partnership, there is no connection of this network, something we could talk about, discuss the problems that come to the service (E8). In many situations, the CREAS professional sees himself alone, we do not have the support we need from the services, especially essential services that should guarantee the protection of the victims with us, but unfortunately in some cases the child is exposed, unprotected (E12). For professionals interviewed there is a lack of articulation and commitment of the network for that service can be effective in the service. Fragmentation, among the various 
services that make up the network (Guardianship Council, Juvenile and Youth Court, Police Station for Child and Adolescent Protection, Social and Health Services, Education, NGOs), constitute an obstacle for professionals as they are unable to continue the recovery and promotion of family health. The lack of effective communication between the different services that integrate the network of care for children and adolescents victims of violence, makes the work of CREAS not very effective, according to the following reports: when a child arrives at the service and, after evaluating, we refer this child to different devices network service, but unfortunately we do not have the return (E7). Besides the difficulty in referrals, there is no reference and counter reference of the cases (E5). When we need to refer a child, we need to get in the queue, so we cannot solve the problem immediately (E1).

Effective action to guarantee the rights of children and adolescents. According to the professionals' report, when families seek help in specialized care services, the first difficulty is in providing care quickly and resolutely, which corroborates the violation of the rights of children and adolescents. Many victims remain in waiting queues for care here at CREAS creating obstacles and even loss of contact of this family (E1). The number of processes accumulated, the bureaucratic procedures, are pointed out by professionals as a routine problem of the specialized service network and that seriously hinders the progress of CREAS. According to the coordinator of the service, delinquency of justice contributes to the violation of the rights of children and adolescents because the response does not come when it is needed, meanwhile the child becomes helpless, often there is evasion of the family and consequently of the victim, which may lead beyond impunity, a possible revictimization of the child and/or adolescent (E11). The problem is even greater when it requires specific measures to protect the victim, such as the removal of the family, due to insufficient institutional shelter programs for children and adolescents in situations of violence
(E4). According to E8, the service to the abuser is not yet a reality in the city due to numerous problems, including the lack of a qualified professional to attend this type of clientele and investments in this type of professional such as training and working conditions (E8).

\section{Challenges of the work of professionals in CREAS}

Lack of investment in training professionals. The interviewed professionals report that although they are able to identify families in situations of vulnerability and risk of intrafamily violence, there is no support from municipal management in refresher courses and periodic training to attend to this clientele (E4). For professionals, working with violence is a topic that in fact requires a lot of technical preparation, which requires updated knowledge about the subject and the exchange of knowledge between different devices (E1). Characterized as an environment with high emotional overload, it is notorious in the speech of professionals, the lack of care and appreciation of these workers by managers. The professional E2, says that the team fee/s unmotivated by lack of professional appreciation and, often, no profile for the type of work. E3, perceives an authoritarian and collecting management, distant from the team and deficient in the needs of the servers. E8 already feels the need to work out the frustrations, since the work depends on other institutions and these, present resistance.

Insufficiency of material and human resources. The accumulation of functions and the lack of human resources has compromised the good progress of the service, according to the professionals' reports. The narratives reveal how this process has been configured: The imposition of the juridical in the questions of producing evidence, is a difficulty that we face, we need to make psychological evaluation reports (E2). The realization of psychological evaluation is not predicted as an activity in CREAS policy, but in 
the accomplishment of psychosocial monitoring, and the fact that we carry out the evaluations, we are very exposed (E5). We need to serve the entire territory and we do not have enough human resources to meet the demand (E9). Difficulties with regard to financial transfers from municipal resources also affect the service. According to the professionals, there are no computers for all employees, which makes it unfeasible, especially in terms of agility and quality of service (E4). Often the difficulty in working on CREAS is the lack of expedient material such as educational games, psychological tests, bibliographies (E1). We miss the printer because we have to move to another device to use the printer (E10). It is noteworthy that fifteen years have passed since the implementation of the service in the municipality and there is still no computerized system for the registration of CREAS information, thus corroborating so that the delays in service are even greater.

\section{Discussion}

The reality found allows us to bring up a problem that occurs in the daily lives of many families, which can corroborate so that silence overcomes the revelation of violence. The results of this study show that the victims are treated in the service; however, they cannot always guarantee the effectiveness of the referrals. The fragmentation of the services that make up the network of care for children and adolescents has compromised the progress of CREAS and, furthermore, exposing the victim to a possible risk of death and injuries that may affect their development. Networking is a strategy that strengthens advocacy, accountability and support for victims of violence. In the meantime, the literature reveals that actors in the networks of attention to situations of violence in the country also recognize that the interinstitutional action, rather than a principle, is an absolute necessity in the face of the complexity of the problem. ${ }^{(11)}$
The testimonies of the subjects are in line with the findings of several studies that affirm that effective and decisive care in the face of a case of violence against children and adolescents goes beyond individual, institutional and social aspects, especially in the establishment of referral and contraceptive systems. ${ }^{(12-14)}$ However, this service network, although highly valued, is considered insufficient, especially in actions directed at children and adolescents who are victims of violence. It is understood that official documents related to violence are put to society, but without a wide and sufficient discussion and mobilization of the protagonists, favoring the maintenance of possible barriers as pointed out in the study. There is a movement to approve laws, ordinances and decrees related to violence, however, it is not enough to approve it only if the network for dealing with violence is disjointed, lacking in inputs and strategies, fragility of knowledge and incipient management in this sphere of violence. ${ }^{(12,13)}$

The discrediting of legal instruments, judicial organs and police authorities, as well as the disqualification of professionals in the specialized care of children and adolescents victims of violence are realities also pointed out in other studies. ${ }^{(15,16)}$ They possibly contribute to that many families choose not to seek care prioritizing to protect themselves "in a wall of silence," meanwhile, children and adolescents remain unprotected. Effective action by law enforcement agencies and the judiciary is key. However, criminal accountability does not mean ensuring peace in family or social relationships. In certain situations, the legal punishment of the aggressor should be added to other measures that contribute to the promotion of a culture of citizenship, accountability and protection of children and adolescents. ${ }^{(17)}$ Integral care for the victim, including the aggressor, may be an important step in the attempt to break the violence, so it is recommended that qualified care be used to re-socialize the agents that cause violence, thus avoiding the recurrence of violence. ${ }^{(18)}$ Although 
it is recommended that the intervention be directed not to only the victim, but also the family as the focus of attention, the results show that professionals have faced structural and economic limitations, which restricts the professional performance in the scope of intervention. It is known that this is not an exclusive difficulty of the municipality, it is also identified in other studies the inter-sectoral difficulties regarding the articulation with the care network, reference processes and against reference and interlocution of the professionals involved. ${ }^{(14,19)}$

The valorization of professional training in attending to situations of violence was one of the actions judged by the interviewees as important, since the decision making in relation to the diagnosis, care, notification and referral of the situation of violence seems to be strongly related to the knowledge of the protection of the victim, represented by legislation, but also as an ethical issue of the professional for the protection of the child under his or her care. ${ }^{(20)}$ The Child and Adolescent Statute (ECA) previse a creation and investment in the qualification and training of professionals to receive and be able to attend the demand of care. ${ }^{(4)}$ Although professionals have built and developed specific knowledge throughout their professional trajectory, many are inserted into the service without any preparation, what they consider as something negative for the service, because their absence increase the chances of failure in care. However, what has been observed is the search by own initiative to take courses and specialization in the area, discuss cases and professional demands as a team.

Support for professionals is essential for the operation of a service. This support encompasses all the investment needed for a policy to take place, and involves the professionals who are relating to it. Thus, it is understood that the strengthening of the care network goes not only through the expansion of specialized services, but also through the permanent training of professionals in order to ensure a qualified care for victims of violence. $(21,22)$ Violence is not limited only to care directed at injuries, but also to a knowledge that allows to handle this problem in a more secure and qualified way, which is in line with what professionals have reported, i.e. the need for training of the teams that work with this clientele. This reinforces the need to "give voice" to these professionals in order to point not only to their desires in relation to their work, but also to health care so that they can be strengthened when the violence face them in their daily work. Thus, strengthened may have a more successful intervention with better care.

Conclusion. The effective protection and guarantee of the rights of children and adolescents is a reality that needs to be addressed, as well as overcoming situations that violate their rights, require knowledge and reflection on how municipalities are articulating in the cases of violence against children and adolescents. It was evidenced in this study that the services that make up the protection network still present weaknesses in the municipality investigated. Unpreparedness about how to work in a network, through lack of communication among workers, lack of return of the services to which the user was referenced, and the lack of accountability of the professionals involved in the care can signal, besides the lack of commitment in the guarantee of right of children and adolescents, limitations of the management and organization of the set of services that make up this network.

Thus, the disarticulation of the network, in fact, is a fragility that requires special attention from municipal management, given the need for protection organs and institutions to be articulated and strengthened, so that their actions are effective. Thus, to qualify the network, qualified and training professionals are needed, as well as the valorization of those involved.

The present study had as limitation its accomplishment in a single scenario, so these analyzes could be limited, since they represent perceptions of a particular group, and it is not possible to generalize the results. Also, it is important to note that, although health professionals are not part of these services, they must always act in an articulated way, in a multiprofessional work, either in the care and in 
the formulation of a care plan focused on the real needs of families. Although the study presents limitations, the data point to the need for new investigations, considering the perception of workers from other sectors of the municipality studied, which would broaden the discussion about the obstacles and the challenges faced and would allow the planning of actions.

This study advances the production of knowledge in that guaranteeing rights to children and adolescents is an urgent necessity that needs to be addressed. It suggests, in addition to the planning of actions with a view to networking, the need for permanent education in order to qualify the protection services of the municipality under investigation.

Acknowledgments: To the National Council for Scientific and Technological Development -CNPq, for the research assistance (Process no 401609 / 2015-4. 


\section{References}

1. Hillis S, Mercy J, Amobi A, Kress H. Global Prevalence of Past-year Violence Against Children: A Systematic Review and Minimum Estimates. Pediatrics. 2016; 137(3):1-13.

2. Walsh J, Spangaro J, Soldatic, K. Global understandings of domestic violence. Nurs. Health Sci. 2015; 17(1):1-4.

3. World Health Organization. Global status report on violence prevention [Internet]. 2014 [cited 20 Dec 2016]. Available from: http://www.who.int/violence_injury_prevention/violence/status_report/2014/en/.

4. Brasil. Estatuto da Criança e do adolescente: lei n. 8.069, de 13 de julho de 1990, e legislação correlata. 9. ed. Brasília: Câmara dos Deputados, Edições Câmara; 2010. Available from: http://www.crianca.mppr.mp.br/arquivos/ File/publi/camara/estatuto_crianca_adolescente_9ed.pdf.

5. Rosa EM, Lira MOSC. Intrafamiliar violence against children and adolescents: support and overcoming network. J Hum. Growth Dev. 2012; 22(2):246-52.

6. Brasil. Ministério da Previdência e Assistência Social. Portaria $n^{\circ}$ 878/2001, de 03 de dezembro de 2001, Estabelece diretrizes e normas do Programa Sentinela, e dá outras providências. Republicada, no Diário Oficial da União, Brasília.

7. Ministério do Desenvolvimento Social (MDS) 2013. CREAS Institucional. [cited 12 Nov 2014]. Available from: http://www.crianca.mppr.mp.br/arquivos/File/suas/creas/creas_institucional.pdf

8. Instituto Brasileiro de Geografia e Estatística. População estimada para o Município do Rio Grande. 2014 [cited 2017 Oct 12]. Available from: http://www.cidades.ibge.gov.br/xtras/perfil.php?lang=\&codmun=431560\&search =riogrande-do-sul $\mid$ rio-grande

9. Childhood Brasil. $6^{\circ}$ Mapeamento de Pontos Vulneráveis à Exploração Sexual de Crianças e Adolescentes nas Rodovias Federais Brasileiras.2014 [cited 2017 Nov 20]. Available from: http://www.namaocerta.org.br/pdf/ Mapeamento2013_2014.pdf

10. Bardin L. Análise de Conteúdo. São Paulo: Edições 70; 2011.

11. Pelisoli C, Pires JPM, Almeida ME. Violência sexual contra crianças e adolescentes: dados de um serviço de referência. Temas Psicol. 2010; 18(1):85-97.

12. Cardoso AVM, Teixeira SM. Políticas de atenção à criança e ao adolescente em situação de risco social. Emancipação. 2017; 17(1):45-57.

13. Ribeiro JP, Silva MRS, Cezar Vaz MR, Silva PA, Silva BT. The protection of children and adolescents: an analysis of public policies and their relationship with the health sector. Invest. Educ. Enferm. 2013; 31(1):133-41.

14. Lopes CS, Brisola EMA. Trabalhadores do centro de referência especializado em assistência social: dificuldades vividas no cotidiano profissional. Rev. Ciênc. Humanas. 2017; 10(20):134-47.

15. Hohendorff JV, Patias ND. Violência sexual contra crianças e adolescentes: identificação, consequências e indicações de manejo. Barbarói. 2017; 49(1):239-57.

16. Souza AMF, Sousa FJP. Avaliação do enfrentamento às violências contra crianças e adolescentes: a experiência da Comissão de Prevenção aos Maus-Tratos em uma Unidade de Saúde da Família da SER V. Rev. Avaliação Polit. Publicas. 2014; 2(14):128-47.

17. Deslandes S, Mendes CHF. Quem avalia, atua melhor! Guia para análise avaliativa dos municípios no enfrentamento da violência intrafamiliar e exploração sexual de crianças e adolescentes. Rio de Janeiro: Fiocruz; 2011.

18. Vieira MS, Grossi PK, Costa RG. O enfrentamento à violência sexual contra crianças e adolescentes: os caminhos para a municipalização das ações em Porto Alegre. Anais $2^{\circ}$ Encontro Internacional de Política Social $9^{\circ}$ Encontro Nacional de Política Social; 2014. Available from: http://repositorio.pucrs.br/dspace/bitstream/10923/9469/2/o_ enfrentamento_a_violencia_sexual_contra_criancas_e_adolescentes_os_caminhos_para_a_municipalizacao_das_ acoes_em_porto.p.pdf

19. Gonçalves CFG, Silva LMP, Pitangui ACR, Silva CC, Santana MV. Atuação em rede no atendimento ao adolescente vítima de violência: desafios e possibilidades. Texto Contexto Enferm. 2015; 24(4):976-83.

20. Silva PA, Lunardi VL, Ribeiro JP, Oliveira AMN, Vasquez TCS. A notificação da violência intrafamiliar contra crianças e adolescentes por profissionais de saúde no Brasil. Av. Enferm. 2015; 33(1):142-50.

21. Deslandes SF, Mendes CHF, Pinto LW. Proposição de um índice do enfrentamento governamental à violência intrafamiliar contra crianças e adolescentes. Cad. Saúde Pública. 2015; 31(8):1709-20.

22. Deslandes SF, Mendes CHF, Luz ES. Análise de desempenho de sistemas de indicadores para o enfrentamento da violência intrafamiliar e sexual contra crianças e adolescentes. Cien. Saude Colet. 2014; 19(3):865-74. 